\title{
Fabrication of Hydroxyapatite Ceramics to Mimic the Natural Bone Structure
}

\author{
Daehee Moon and Su Chak Ryu ${ }^{\dagger}$ \\ Department of Nanomedical Engineering, Pusan National University, Miryang 627-706, Korea
}

(Received August 12, 2011; Revised September 6, 2011; Accepted September 14, 2011)

\begin{abstract}
The objective of our study was to produce an imitation bone material consisting of hydroxyapatite with a compact and spongy structure. This study shows the ideal content of $\mathrm{SiO}_{2}$ and the sintering temperature to produce imitation bone that has the mechanical properties of natural bone. On the basis of our determination of the ideal conditions, a compact part was produced and its mechanical properties were tested. A compact part made of $0.5 \mathrm{wt} \% \mathrm{SiO}_{2}$ and sintered at $1350^{\circ} \mathrm{C}$ showed excellent mechanical properties. The bioactivity of the compact part under this condition was tested, and it was found to be bioactive. The porous part was produced by controlling the powder size, and the dual structure was manufactured by combining the compact and porous parts. A water permeability test confirmed that the dual structure had an interconnected pore structure. Therefore, this dual-body structure is feasible for use in the creation of implants.
\end{abstract}

Key words: Hydroxyapatite, Dual, Porous, Compact, Implant

\section{Introduction}

$\mathrm{T}$ he demand for bone grafts of various forms has increased owing to the advancements in medical technology. Earlier, damaged bone was usually removed, but in recent years, biomaterials have been used to replace or regenerate the damaged bone area. These biomaterials must be chemically stable and free from the potential for infection and contamination. ${ }^{1-3)}$

In recent years, hydroxyapatite $\left[\mathrm{Ca}_{10}\left(\mathrm{PO}_{4}\right)_{6}(\mathrm{OH})_{2}, \mathrm{HAp}\right]$ has attracted much attention as a biomaterial because its chemical composition is identical to that of human bone. Moreover, it has excellent biocompatibility, osseointegration, and biostability. ${ }^{4,5)}$ HAp is a highly biocompatible and bio-adoptable natural ceramic with remarkable biological stability and non-viral effects. Furthermore, its unique characteristic-osteoconduction ${ }^{6-9)}$ in host osseous materials-has been employed in dental implants ${ }^{10-14)}$ and in bone cement applications. ${ }^{15-17)}$ In particular, HAp has been used in numerous situations and fields, including orthopedic surgery, immediate tooth replacement, as a pulpcapping material, and for the repair of bone defect. Natural bone has a dual structure that consists of compact bone, which has excellent mechanical strength, and porous bone, which has good properties for the blood circulation and cell supply. This dual structure satisfies the functions of the scaffold required in the human body as well as the pathways of blood circulation and neurons. One of the key issues in the production of imitation bone is the development of a scaffold that satisfies

\footnotetext{
${ }^{\dagger}$ Corresponding author: Su Chak Ryu

E-mail : scryu@pusan.ac.kr

Tel : +82-51-350-5878 Fax : +82-51-350-5839
}

these functions.

Our purpose for the production of the dense HAp part is to ensure that the mechanical properties are similar to those of real bone. It is well known that the factors that influence the mechanical properties of sintered ceramic are the additive, sintering temperature, powder size and molding pressure. From among these factors, we chose two variable factors in this experiment: the additive $\left(\mathrm{SiO}_{2}\right)$ and the sintering temperature. ${ }^{18)}$ Many studies have attempted the production of porous HA ceramics using polymer foam, polymer beads, lithography technology and freeze casting. ${ }^{19-21)}$ We suggest a new and simple method for the production of porous HA ceramics. The objective of our study is to find the ideal content of $\mathrm{SiO}_{2}$ that must be used and the sintering temperature that must be maintained to develop a bone replacement that satisfies the mechanical properties of natural bone and that generates the dual structure. The porous part was produced by controlling the powder size. Through our efforts, we produced an imitation bone material with compact (outside) and porous (inside) parts made of sintered HAp.

\section{Experimental Procedure}

The experiment was performed in three steps: the manufacture of the outside body, the manufacture of the inside body and the combining of the outside body and the inside body. Fig. 1 shows the overall experimental procedure. The HAp (Bone Tech, Busan, Korea) used in this study was a fine and coarse powder with no notable agglomeration. Detailed properties of this material are available in the literature. ${ }^{22-24)}$ An X-ray diffractometer (Miniflex II, Rigaku, Japan) was used to analyze the crystal phase of the HAp powder. A universal testing machine (SMB-001-5T, SM TEST, Korea) was 
(a)

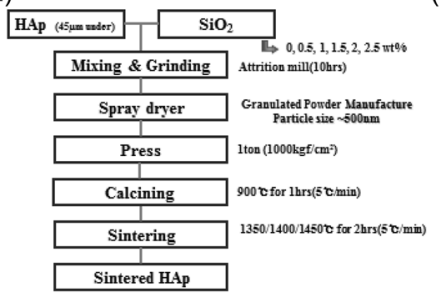

(b)

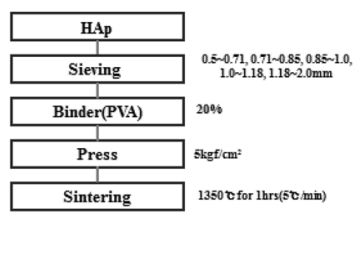

(c)

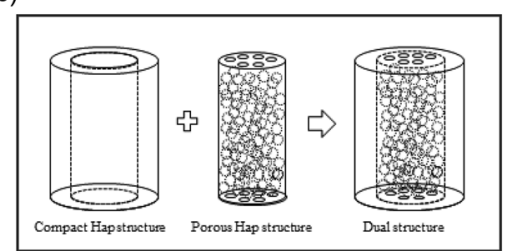

Fig. 1. Experimental procedure: (a) the procedure for the manufacture of the compact HAp, (b) the procedure for the manufacture of the porous HAp, and (c) the manufacturing process of the dual structure.

used to measure the bending and compressive strength of the outside body, and a hardness test was performed using a micro-Vicker's hardness tester (FM-700, Future Tech, Japan). Scanning electron microscopy (SEM, Hitachi S-4200, Hitachi, Japan) was utilized to observe the sintered microstructure and the surface after treatment in a simulated body fluid (SBF) solution.

\subsection{Manufacture of the outside body}

To fabricate the outside body, HAp powder measuring less than $45 \mu \mathrm{m}$ was mixed with $\mathrm{SiO}_{2}$ (Junsei Chemical Co., Ltd., 98.0\%) and ground using an attrition mill for $10 \mathrm{~h}$. The granular powder was produced using a spray dryer. The HAp powder was modified after mixing with different contents of $\mathrm{SiO}_{2}$, which varied from $0 \mathrm{wt} \%$ to $2.5 \mathrm{wt} \%$ (at $0.5 \mathrm{wt} \%$ ratios); the properties were investigated and the mixed powder was molded by uniaxial pressing at $1000 \mathrm{kgf} / \mathrm{cm}^{2}$ using a specially manufactured mold (outside and inside diameter : $14 \mathrm{~mm}$ and $8 \mathrm{~mm}$, respectively). The pressed specimens were sintered in an electric furnace for $2 \mathrm{~h}$ at different temperatures$1350^{\circ} \mathrm{C}, 1400^{\circ} \mathrm{C}$, and $1450^{\circ} \mathrm{C}$-after calcining at $900^{\circ} \mathrm{C}$ for $1 \mathrm{~h}$ (heating rate, $5^{\circ} \mathrm{C} / \mathrm{min}$ ). Fig. 1 (a) shows the experimental procedure for the manufacture of the outside body. The sintered specimen was analyzed using an X-ray diffractometer (Miniflex II, Rigaku, Japan) with $\mathrm{Cu} \mathrm{K} \alpha$ radiation generated at $3 \mathrm{kV}$ and $15 \mathrm{~mA}$ between $10^{\circ}<2 \theta<80^{\circ}$ at a scan speed of $4 \% \mathrm{~min}$. The X-ray diffraction (XRD) patterns were analyzed and compared with the Joint Committee on Powder Diffraction Standards (JCPDS) card (\# 9-432). The compressive test was carried out using a universal testing machine (SMB-001-5T, SM TEST, Korea, 50KN load cell) at a cross-head speed of $1 \mathrm{~mm} / \mathrm{min}$. The specimen was prepared using a cylinder mold $4.5 \varnothing \times 12(\mathrm{~mm})$ in size. A bending test was carried out using a U.T.M at a cross-head speed of $1 \mathrm{~mm} / \mathrm{min}$. The specimen was prepared at a size of $4.5 \times 25 \times 1.5(\mathrm{~mm})$. 10 specimens were tested, and the average strength was calculated not including the maximum-minimum values. A hardness test of the outside body was performed using a micro-Vicker's hardness tester (FM-700, Future Tech, Japan) at $10 \mathrm{gf} / \mathrm{mm}^{2}$. Scanning electron microscopy (SEM, Hitachi S-4200, Hitachi, Japan) was utilized to observe the sintered microstructure and the surface after exposure to the simulated body fluid (SBF) solution.

\subsection{Manufacture of the inside body}

In this study, we used a theoretically calculated powder size of $0.2-1.2 \mathrm{~mm}^{20)}$ to obtain a pore size of $100-300 \mu \mathrm{m}$, which is the most appropriate pore size required for the survival and growth of bone tissue. ${ }^{25)}$ The HAp powder was sorted by the sieve method depending on the powder size: $0.50-0.71 \mathrm{~mm}$, $0.71-0.85 \mathrm{~mm}, 0.85-1.00 \mathrm{~mm}, 1.00-1.18 \mathrm{~mm}$, or $1.18 \mathrm{~mm}-$ $2.00 \mathrm{~mm}$. The sorted HAp powders were mixed with $20 \mathrm{wt} \%$ of a bonding agent and molded by uniaxial pressing at $5 \mathrm{kgf} / \mathrm{cm}^{2}$ using a cylindrical mold (diameter, $9.8 \mathrm{~mm}$ ). The pressed specimens were sintered in an electric furnace for $2 \mathrm{~h}$ at $1350^{\circ} \mathrm{C}$ (heating rate, $5^{\circ} 5 / \mathrm{min}$ ). Fig. $1(\mathrm{~b})$ shows the experimental procedure of the manufacture of the HAp-sintered inside body. The morphology of the sintered specimen was observed under an optical microscope (SMZ 2000, Nikon, Japan), and the volumetric porosity, maximum pore area, and the average pore size were analyzed by the 'I-pro program', which is calculating software.

\subsection{Manufacture of the dual-body structure}

After the calcined outside body was combined with the inside body, the dual-body structure was sintered in an electric furnace for $2 \mathrm{~h}$ at $1350^{\circ} \mathrm{C}$ (heating rate, $5^{\circ} \mathrm{C} / \mathrm{min}$ ). Fig. 1(c) shows the manufacturing process of the dual-body structure. The water permeability of the dual-body structure was determined by passing water though the top of the structure.

\section{Results and Discussion}

Fig. 2 shows XRD patterns of the HAp sintered at different temperatures with different $\mathrm{SiO}_{2}$ contents. For the specimen with $0 \mathrm{wt} \% \mathrm{SiO}_{2}$, the XRD results showed only the general peak of the HAp crystal. On the other hand, for the specimens with 0.5-2.5 wt\% $\mathrm{SiO}_{2}$, the XRD results showed HAp crystal and $\beta$-tricalcium ( $\beta$-TCP) crystal peaks. The intensity of the $\beta$-TCP crystal peaks increased as the $\mathrm{SiO}_{2}$ content increased. It was considered that a phase transition to $\beta$-TCP as glass $\mathrm{SiO}_{2}-\mathrm{CaO}$ or $\mathrm{SiO}_{2}-\mathrm{CaO}-\mathrm{P}_{2} \mathrm{O}_{5}$ occurred due to the reaction between $\mathrm{HAp}$ and $\mathrm{SiO}_{2}$ during the sintering process. ${ }^{26,27)}$ Figs. 3-5 show the hardness, bending strength, and the compressive strength of sintered HAp that was manufactured at different temperatures and using different $\mathrm{SiO}_{2}$ contents. The outside body, which was sintered at $1350^{\circ} \mathrm{C}$, showed excellent mechanical properties compared to the samples sintered at other temperatures. For the specimens with a high content of $\mathrm{SiO}_{2}$, the hardness, compressive strength, and the bending strength of the outside body decreased from $350.4 \mathrm{Hv}$ 

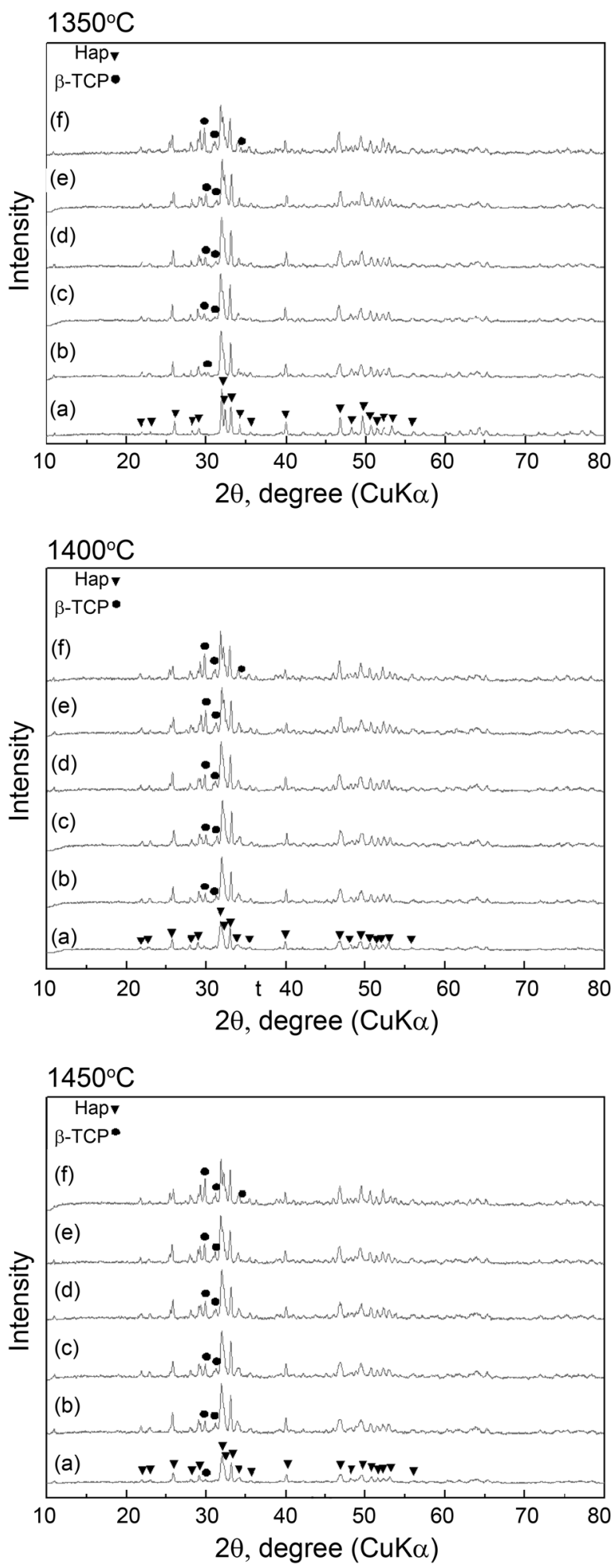

Fig. 2. XRD patterns of HAp mixed with different $\mathrm{SiO}_{2}$ contents and sintered at $1350^{\circ} \mathrm{C}, 1400^{\circ} \mathrm{C}$, and $1450^{\circ} \mathrm{C}$ for $2 \mathrm{~h}$ : (a) 0 , (b) 0.5 , (c) 1 , (d) 1.5 , (e) 2 , and (f) $2.5 \mathrm{wt} \%$.

to $230.8 \mathrm{Hv}$, from $285.72 \mathrm{MPa}$ to $155.91 \mathrm{MPa}$, and from 75.035 $\mathrm{MPa}$ to $51.88 \mathrm{MPa}$, respectively, at $1350^{\circ} \mathrm{C}$.

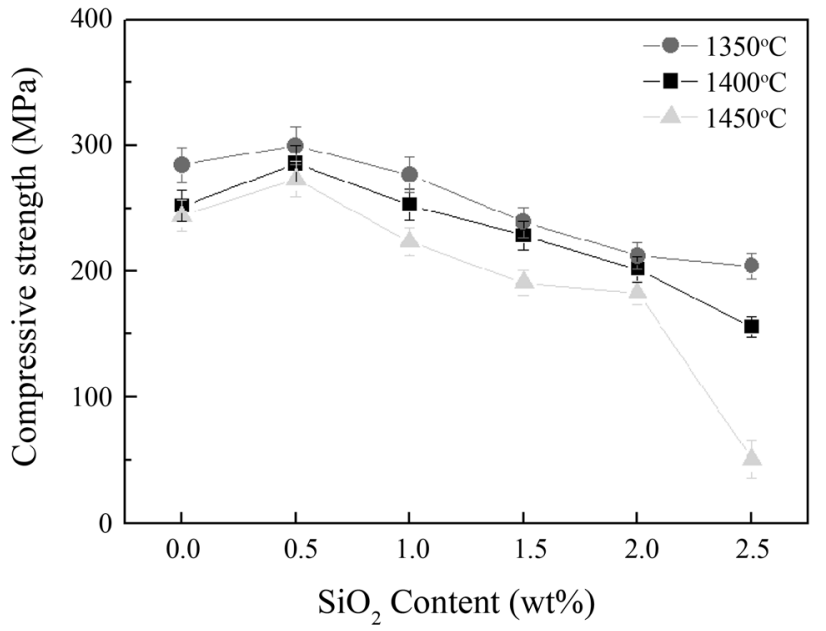

Fig. 3. Compressive strength of HAp mixed with different $\mathrm{SiO}_{2}$ contents and sintered at $1350^{\circ} \mathrm{C}, 1400^{\circ} \mathrm{C}$, and $1450^{\circ} \mathrm{C}$ for $2 \mathrm{~h}$.

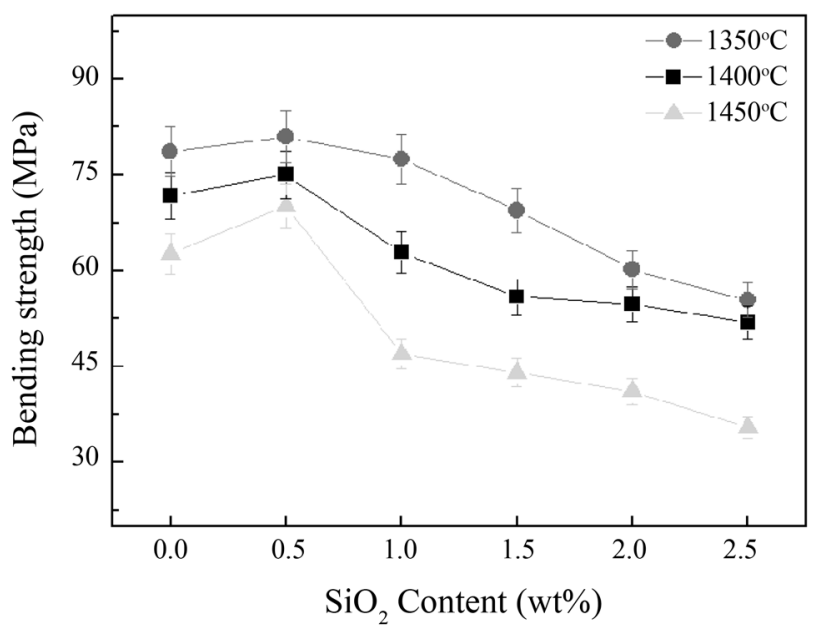

Fig. 4. Bending strength of HAp mixed with different $\mathrm{SiO}_{2}$ contents and sintered at $1350^{\circ} \mathrm{C}, 1400^{\circ} \mathrm{C}$, and $1450^{\circ} \mathrm{C}$ for $2 \mathrm{~h}$.

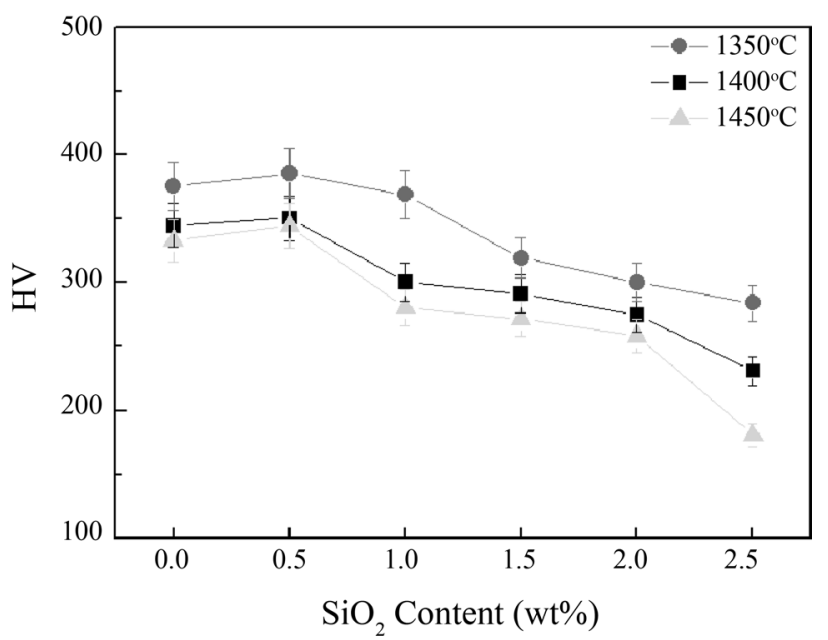

Fig. 5. Micro-Vicker's hardness test for HAp mixed with different $\mathrm{SiO}_{2}$ contents and sintered at $1350^{\circ} \mathrm{C}, 1400^{\circ} \mathrm{C}$, and $1450^{\circ} \mathrm{C}$ for $2 \mathrm{~h}$. 
Our results showed that the specimen with $0.5 \mathrm{wt} \% \mathrm{SiO}_{2}$ sintered at $1350^{\circ} \mathrm{C}$ was a high-strength sample (compressive strength of $295.72 \mathrm{MPa}$, bending strength of $77.55 \mathrm{MPa}$, micro-Vicker's hardness of $350.4 \mathrm{HV}$ ). In the other specimens (1.0-2.5 wt $\% \mathrm{SiO}_{2}$ content), it was likely that the increase in the $\beta$-TCP crystal phase led to a decrease in the mechanical properties. Fig. 6 shows a SEM image of the sintered HAp
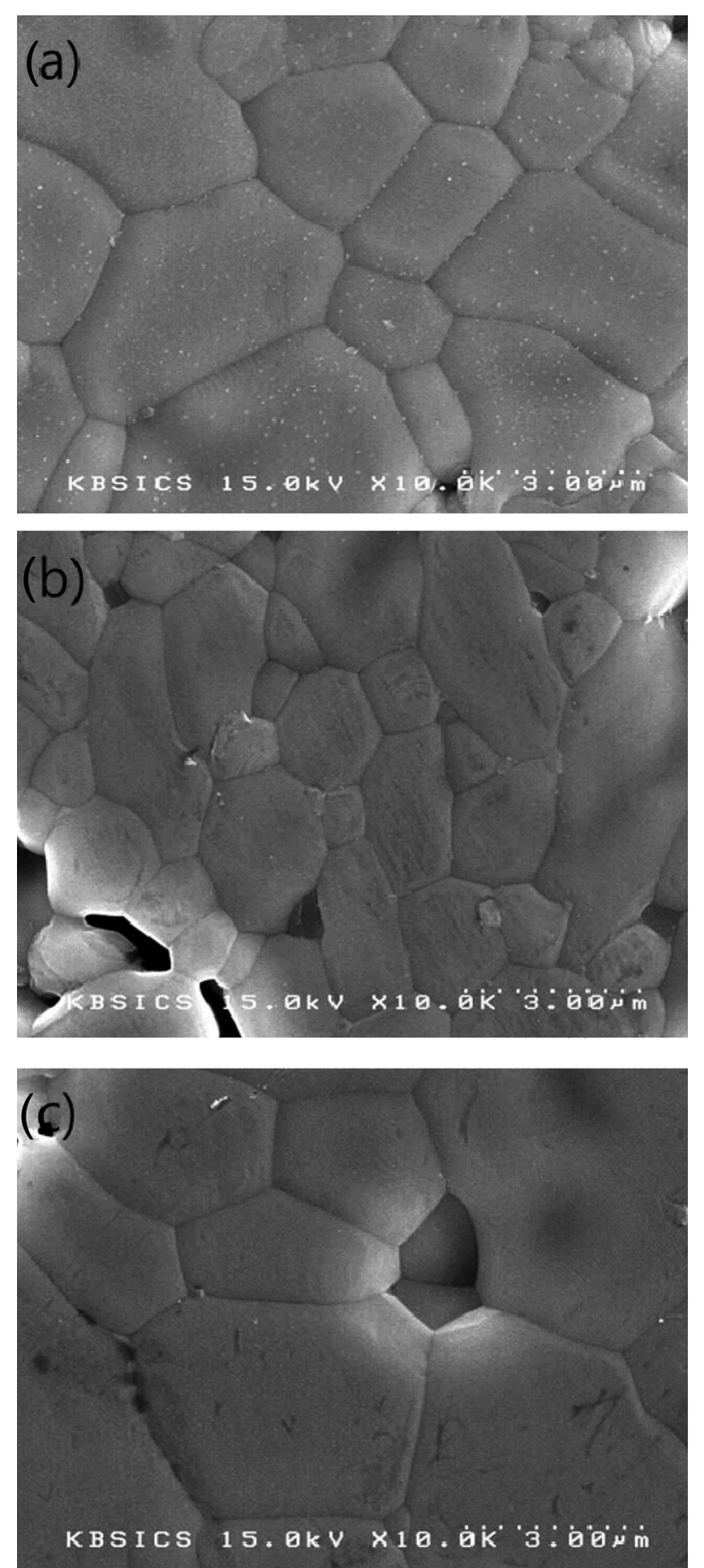

Fig. 6. SEM images showing the morphologies of HAp mixed with $0.5 \mathrm{wt} \% \mathrm{SiO}_{2}$ and sintered at different temperatures: (a) $1350^{\circ} \mathrm{C}$, (b) $1400^{\circ} \mathrm{C}$, and (c) $1450^{\circ} \mathrm{C}$ for $2 \mathrm{~h}$. mixed with $0.5 \mathrm{wt} \% \mathrm{SiO}_{2}$. This sample shows excellent mechanical properties at every sintering temperature. As the sintering temperature increases, the grain of the sintered HAp becomes denser but the pore size increases. This implies a melting process of the glass $\mathrm{SiO}_{2}-\mathrm{CaO}$ or $\mathrm{SiO}_{2}-\mathrm{CaO}-\mathrm{P}_{2} \mathrm{O}_{5}$ as the temperature increases ${ }^{28)}$. Fig. 7 shows the result of the bioactivation test in the $\mathrm{SBF}$ solution at $1350^{\circ} \mathrm{C}$. A change in the microstructure due to the activation reaction in the SBF solution was observed. In addition, sintered HAp with $0.5 \mathrm{wt} \% \mathrm{SiO}_{2}$ added to it shows excellent bioactivity and excellent mechanical properties, identical to pure HAp. The pore size and the porosity measurement results of the inside body are shown in Fig. 8 . The porosity increased from $25.985 \%$ to $44.203 \%$ as the powder size increased, but the pore size showed an irregular trend because the particle cracked during the press process.

Table 1 shows the results of the 3-D pore size. The values of the average pore size for 3-D spherical pores were calculated by Fullman's theory, ${ }^{29)}$ in which the 2 -D average radius is multiplied by $\pi / 2$. Among the various powder sizes, a powder size of 1.18-2.00 $\mathrm{mm}$ was selected because this size had the proper pore size $(210.49 \mu \mathrm{m})$ and maximum porosity $(44.203 \%)$. These values are the most appropriate for the survival and
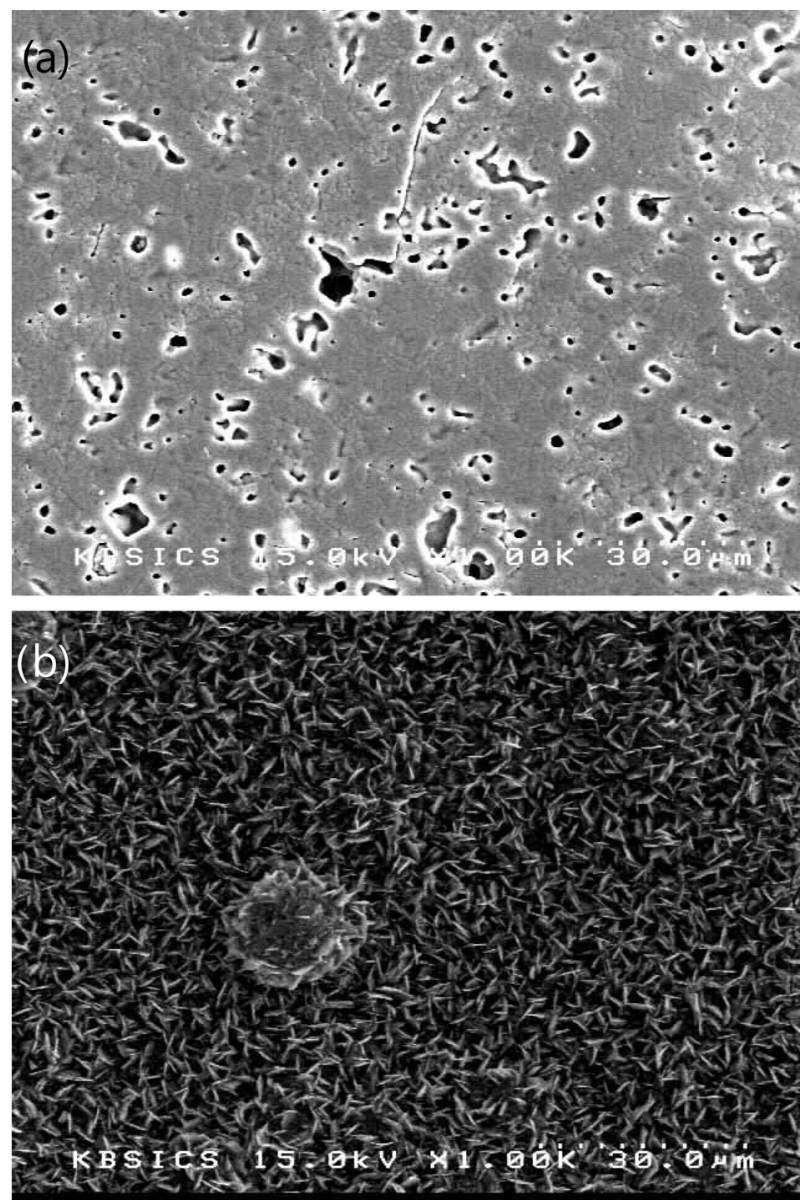

Fig. 7. SBF activation test of $\mathrm{HAp}$ with $0.5 \mathrm{wt} \% \mathrm{SiO}_{2}$ and sintered at $1350^{\circ} \mathrm{C}$ for $2 \mathrm{~h}$ : (a) before immersion, (b) after 8 weeks. 


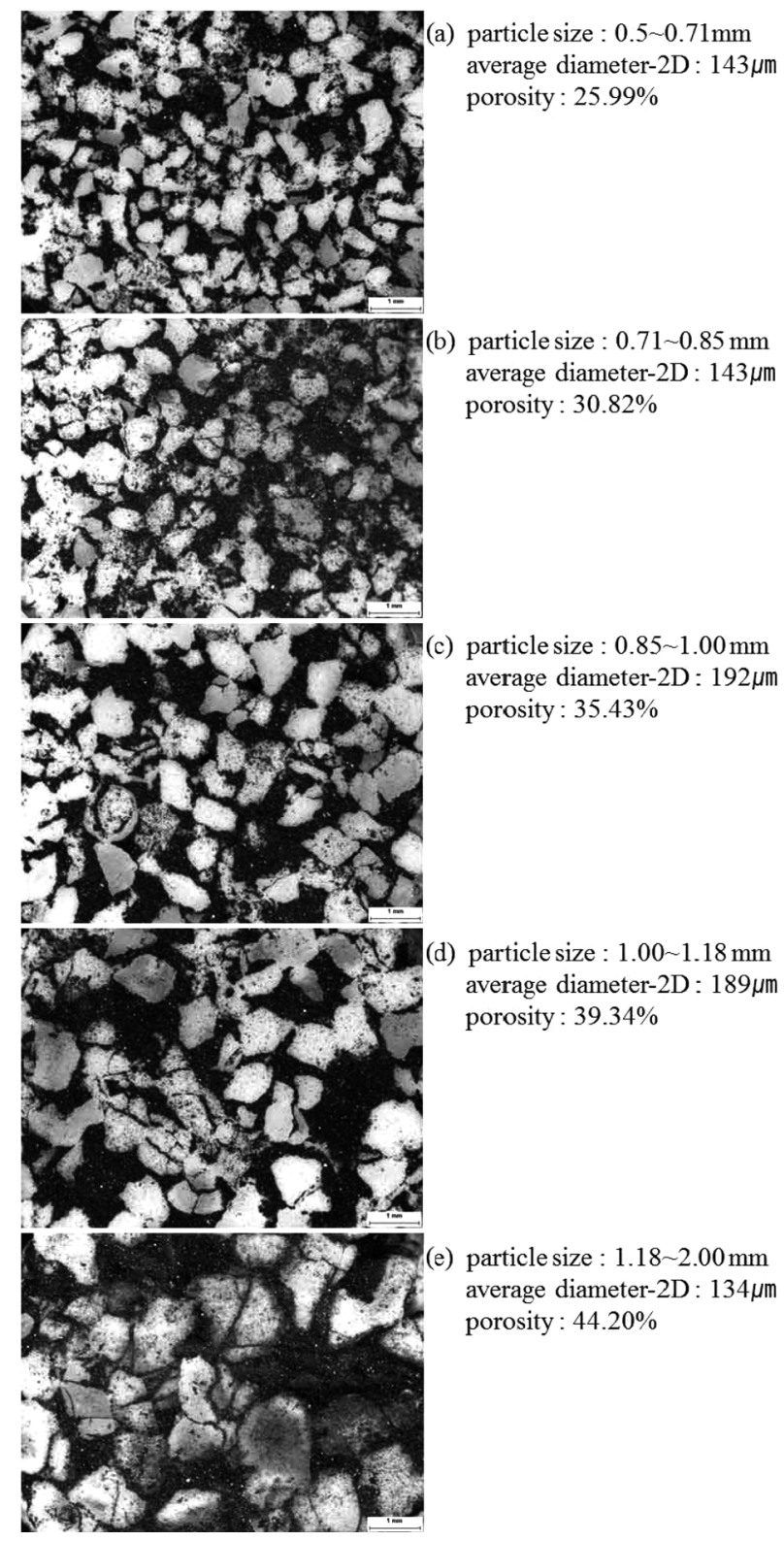

Fig. 8. Pore analysis of the porous HAp structure.

Table 1. Average Diameter of a 3D Pore

\begin{tabular}{ccc}
\hline Specimen & Powder size $(\mathrm{mm})$ & Average diameter-3D $(\mu \mathrm{m})$ \\
\hline $\mathrm{a}$ & $0.5-0.71$ & 224.62 \\
$\mathrm{~b}$ & $0.71-0.85$ & 224.62 \\
$\mathrm{c}$ & $0.85-1.0$ & 301.59 \\
$\mathrm{~d}$ & $1.0-1.18$ & 296.88 \\
$\mathrm{e}$ & $1.18-2.0$ & 210.49 \\
\hline
\end{tabular}

growth of bone tissue. ${ }^{6}$ Therefore, these appropriate pores should enhance the initial tissue response and tissue generation. The result of the water permeability test for the dual-body structure (combined compact and porous structures) is shown in Fig. 9. The pores in the porous structure were effectively formed, as drops of water passed through the porous structure.

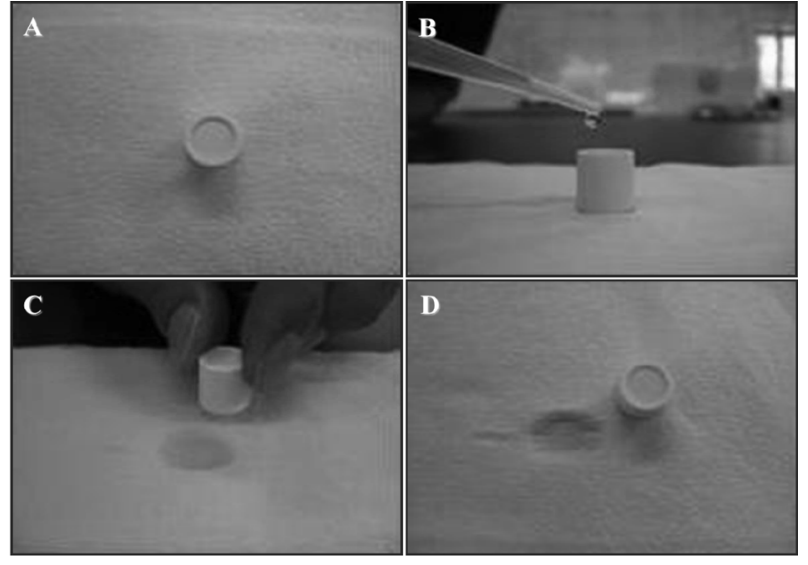

Fig. 9. Experimental procedure and result of the water permeability test.

Given the results outlined above, we can conclude that the dualbody structure is suitable for use as a bone scaffolding material.

\section{Conclusions}

In this study, various temperatures for sintering and different $\mathrm{SiO}_{2}$ contents were analyzed to find the optimal conditions required for the production of an imitation bone that has the mechanical properties of natural bone. The specimen with $0.5 \mathrm{wt} \% \mathrm{SiO}_{2}$ sintered at $1350^{\circ} \mathrm{C}$ had excellent mechanical properties (compressive strength of $295.72 \mathrm{MPa}$, bending strength of 77.55 MPa, and micro-Vicker's hardness of $350.4 \mathrm{Hv}$ ); moreover, the surface of this specimen was shown to be an excellent bioactive microstructure. Therefore, these conditions were used to manufacture the outside structure of the dual-body structure. To obtain a proper pore size for cell growth, the pore size must be calculated according to the HAp powder size and assessed with carefully calculated powder size intervals. The results showed that the proper pore size is $210-300 \mu \mathrm{m}$, which must be used to ensure the creation of a porous HAp structure. After the dual-body structure was produced, a water permeability test was performed, which also yielded good results. Therefore, a dual-body structure having two different features is possible. We conclude that the proposed dual-body structure is suitable for use as a bone scaffolding material.

\section{REFERENCES}

1. J. A. Hubbell, "Biomaterials in Tissue Engineering," Nat Biotech, 13 [6] 565-76 (1995).

2. Langer R and Vacanti JP, "Tissue Engineering," Science, 260 [5110] 920-26 (1993).

3. W. W. Minuth, M. Sittinger, and S. Kloth, "Tissue Engineering: Generation of Differentiated Artificial Tissues for Biomedical Applications," Cell and Tissue Research, 291 [1] 1-11 (1997).

4. R. B. Martin, "Bone as a Ceramic Composite Material," Materials Science Forum, 293 5-16 (1999).

5. C. R. Nunes, S. J. Simske, R. Sachdeva, and L. M. Wolford, 
"Long-term Ingrowth and Apposition of Porous Hydroxylapatite Implants," J. Biomed. Mater. Res., 36 [4] 560-63 (1997).

6. H. Yoshikawa and A. Myoui,"Bone Tissue Engineering with Porous Hydroxyapatite Ceramics," J. Artificial Organs, 8 [3] 131-36 (2005).

7. E. A. Monroe, W. Votava, D. B. Bass, and J. M. Mullen, "New Calcium Phosphate Ceramic Material for Bone and Tooth Implants," J. Dental Research, 50 [4] 860-61 (1971).

8. N. Tamai, A. Myoui, T. Tomita, T. Nakase, J. Tanaka, T. Ochi, and H. Yoshikawa, "Novel Hydroxyapatite Ceramics with an Interconnective Porous Structure Exhibit Superior Osteoconduction in Vivo," J. Biomed. Mater. Res., 59 [1] 110-17 (2002).

9. S. R. Levitt, P. H. Crayton, E. A. Monroe, and R. A. Condrate, "Forming Method for Apatite Prostheses," J. Biomed. Mater. Res., 3 [4] 683-84 (1969).

10. M. Ogiso, "Reassessment of Long-term use of Dense HA as Dental Implant: Case Report," J. Biomed. Mater. Res., 43 [3] 318-20 (1998).

11. T.-M. G. Chu, D. G. Orton, S. J. Hollister, S. E. Feinberg, and J. W. Halloran, "Mechanical and in Vivo Performance of Hydroxyapatite Implants with Controlled Architectures," Biomaterials, 23 [5] 1283-93 (2002).

12. R. A. Ayers, S. J. Simske, C. R. Nunes, and L. M. Wolford, "Long-term Bone Ingrowth and Residual Microhardness of Porous Block Hydroxyapatite Implants in Humans," J. Oral and Maxillofacial Surgery, 56 [11] 1297-301 (1998).

13. L. Le GuӨhennec, A. Soueidan, P. Layrolle, and Y. Amouriq, "Surface Treatments of Titanium Dental Implants for Rapid Osseointegration," Dental Materials, 23 [7] 844-54 (2007).

14. M. H. Fathi, M. Salehi, A. Saatchi, V. Mortazavi, and S. B. Moosavi, "In Vitro Corrosion Behavior of Bioceramic, Metallic, and Bioceramic-metallic Coated Stainless Steel Dental Implants," Dental Materials, 19 [3] 188-98 (2003).

15. J. P. Schmitz, J. O. Hollinger, and S. B. Milam, "Reconstruction of Bone using Calcium Phosphate Bone Cements: A Critical Review," J. Oral and Maxillofacial Surgery, 57 [9] 1122-26 (1999).

16. Z. Mazor, M. Peleg, A. K. Garg, and G. Chaushu, "The Use of Hydroxyapatite Bone Cement for Sinus Floor Augmentation with Simultaneous Implant Placement in the Atrophic Maxilla. A Report of 10 Cases," J. Periodontology, 71 [7] 1187-94 (2000).

17. S. Deb, M. Braden, and W. Bonfield, "Water Absorption
Characteristics of Modified Hydroxyapatite Bone Cements," Biomaterials, 16 [14] 1095-100 (1995).

18. S. C. Ryu, S.-H. Min, and Y.-M. Park, "Mechanical Properties of Hydroxyapatite $\beta$-TCP Composite with Changing $\mathrm{SiO}_{2}$ Contents,” Kor. J. Mater. Res., 17 [9] 480-83 (2011).

19. S. Blindow, M. Pulkin, D. Koch, G. Grathwohl, and K. Rezwan, "Hydroxyapatite/ $\mathrm{SiO}_{2}$ Composites via Freeze Casting for Bone Tissue Engineering," Adv. Eng. Mater., 11 [11] 875-84 (2009).

20. M. O. Dean, "Fabrication of Hydroxyapatite Ceramic with Controlled Porosity," J. Mater. Sci.: Mater. Medicine, 8 [4] 227-32 (1997).

21. J. Y. Kim, J. W. Lee, S. J. Lee, E. K. Park, S. Y. Kim, and D. W. Cho, "Development of a Bone Scaffold using HA Nanopowder and Micro-stereolithography Technology," Microelectro. Engi., 84 [5-8] 1762-65 (2005).

22. S. H. Kim, B. K. Lim, F. Sun, K. Koh, S. C. Ryu, H. S. Kim, and J. Lee, "Preparation of High Flexible Composite Film of Hydroxyapatite and Chitosan," Polymer Bulletin, 62 [1] 111-8 (2009).

23. S. C. Ryu, B. K. Lim, F. Sun, K. Koh, D. W. Han, and J. Lee, "Regeneration of a Micro-Scratched Tooth Enamel Layer by Nanoscale Hydroxyapatite Solution," Bull. Kor. Chem. Soc., 30 [1] 887-90 (2009).

24. B. K. Lim, S. C. Ryu, F. Sun, K. Koh, D. W. Han, and J. Lee, "Hydroxyapatite Coating on Damaged Tooth Surfaces by Immersion," Biomedical Materials, 4 [2] 025017 (2009).

25. N. Kot, M. Timutin, and F. Korkusuz, "Fabrication and Characterization of Porous Tricalcium Phosphate Ceramics," Ceram. International, 30 [2] 205-11 (2004).

26. M. Sayer, A. D. Stratilatov, J. Reid, L. Calderin, M. J. Stott, X. Yin, M. MacKenzie, T. J. N. Smith, J. A. Hendry, and S. D. Langstaff, "Structure and Composition of Silicon-stabilized Tricalcium Phosphate," Biomaterials, 24 [3] 369-82 (2003).

27. S. Padilla, J. Rombn, S. Sbnchez-Salcedo, and M. Vallet-Regi, "Hydroxyapatite/ $\mathrm{SiO}_{2}-\mathrm{CaO}-\mathrm{P}_{2} \mathrm{O}_{5}$ Glass Materials: In Vitro Bioactivity and Biocompatibility," Acta Biomaterialia, 2 [3] 331-42 (2006).

28. A. Mortier, J. Lemaitre, L. Rodrique, and P. G. Rouxhet, "Synthesis and Thermal Behavior of Well-crystallized CalciumDeficient Phosphate Apatite," J. Solid State Chem., 78 [2] 21519 (1989).

29. R. L. Fullman, "Measurement of Particle Sizes in Opaque Bodies," Trans. Metall. Soc. AIME, 197 447-52 (1953). 